\title{
Focus and prominence in Chichewa, Chitumbuka and Durban Zulu*
}

\author{
Laura J. Downing
}

Zentrum für Allgemeine Sprachwissenschaft, Berlin

Much work on the interaction of prosody and focus assumes that, crosslinguistically, there is a necessary correlation between the position of main sentence stress (or accent) and focus, and that an intonational pitch change on the focused element is a primary correlate of focus. In this paper, I discuss primary data from three Bantu languages - Chichewa, Durban Zulu and Chitumbuka - and show that in all three languages phonological re-phrasing, not stress, is the main prosodic correlate of focus and that lengthening, not pitch movement, is the main prosodic correlate of phrasing. This result is of interest for the typology of intonation in illustrating languages where intonation has limited use and where, notably, intonation does not highlight focused information in the way we might expect from European stress languages.

\section{Introduction}

In this paper, I investigate the role of intonation - defined as phrase or sentence level prominence-related prosody - in three Bantu languages. Following work like Cruttenden (1997), Jun (2005), Ladd (1996), Gussenhoven (2004), I assume that length, loudness or intensity, and/or pitch are the primary prosodic

\footnotetext{
I would like to thank my collaborators and linguistic consultants for their cooperation in collecting the data presented here and for their assistance in analyzing some phonetic and morpho-syntactic aspects of it: Al Mtenje and Bernd Pompino-Marschall for Chichewa, Meritta Xaba, Leston Buell and Lisa Cheng for Durban Zulu, and Dyman Kondowe and Tionge Kalua for Chitumbuka. My thanks to the Centre for Language Studies in Zomba, Malawi, for hosting me during two research visits to Malawi, and to the NWO for a grant which supported a visit to Leiden, where the Durban Zulu research has been conducted. I am also grateful to the audiences at the ICPhS 2007 Satellite Workshop on Intonational Phonology: Understudied or Fieldwork Languages and at the Gösta Bruce Symposium as well as the two editors of this volume for thoughtful comments on this paper.
} 
correlates of intonational prominence. Whereas most work on intonation has been concerned with pitch (movement), I show that in these Bantu languages another prosody - culminative vowel lengthening - fulfills the demarcative function of providing a prosodic cue to syntactic boundaries (or other groupings at the phrase or sentence level) that pitch accent provides in more familiar European languages.

In many languages, sentence level prosody is conditioned not only by syntactic factors but also by semantic ones, primarily focus and utterance type, like question vs. declarative (see Bruce 1977; Gussenhoven 1984, 1996, 2004; Ladd 1996 and many others). That is, the same type of prosody often can serve two functions, signaling both constituent edges and information structure. Indeed, much work on the interaction of prosody and focus assumes that, crosslinguistically, there is a necessary correlation between the position of sentential prominence (or accent) and focus. The formulation below comes from SamekLodovici (2005: 697), and very similar proposals are found in: Reinhart 1995; Selkirk 1984, 1995, 2004; Roberts 1998; Rooth 1992, 1996; Szendröi 2003; Truckenbrodt 1995:

\section{(1) Prominence-Focus}

For any $\mathrm{XP}_{\mathrm{f}}$ and $\mathrm{YP}$ in the focus domain of $\mathrm{XP}_{\mathrm{f}}, \mathrm{XP}_{\mathrm{f}}$ is prosodically more prominent than $\mathrm{YP}$,

In other words, a focused element $\left(\mathrm{XP}_{\mathrm{f}}\right)$ is required to have the culminative (i.e., highest) level of some suprasegmental feature which correlates with prominence - pitch, duration and/or amplitude or intensity - in its prosodic domain, normally, the Intonation Phrase. For example, in English, 'normal' sentence stress is sentence-final. However, a sentence-initial focused subject must receive sentence stress. That is, sentence stress must 'move' in English to satisfy the Prominence-Focus correlation, as shown in (2), where small caps indicate the word with sentence stress:

(2) Broad vs. narrow focus and stress in English (Samek-Lodovici 2005: 688)
(a) [John has LAUGHED. $]_{\mathrm{f}}$
Context: What happened?
(b) $[\mathrm{JOHN}]_{\mathrm{f}}$ has laughed.
Context: Who has laughed?
(c) $*[\mathrm{John}]_{\mathrm{f}}$ has LAUGHED.
Context: Who has laughed?

However, other work on intonation, like Ladd (1996) and Hayes \& Lahiri (1991), has pointed out that the PROMINENCE-Focus correlation in (1) is mainly supported by European word stress languages like English where cues for sentence level prominence co-occur on the head syllable of focused constituents. A more universal correlate of focus, they argue, is prosodic (re-)phrasing: 
narrow focused constituents trigger different prosodic phrasing from broad focused constituents. Sentence level prominence is a potential - not universal cue to prosodic phrasing, not directly to focus. I show that sentential or phrasal prominence is not a correlate of focus in these three Bantu languages, as we find numerous mismatches between prominence and focus. These languages support the proposal that prominence is, indeed, a cue to phrasing and that phrasing, rather than prominence, is the more universal correlate of focus.

\section{Prosodic phrasing and stress in Durban Zulu, Chichewa and Chitumbuka}

Chichewa and Chitumbuka are two of the three major languages of Malawi (Yao is the third). Durban Zulu is a dialect of one of South Africa's official languages. This section presents the prosodic phrasing algorithms for the three languages, showing the role of syntax and focus in conditioning prosodic phrasing. The data and phonological analysis presented in this section come from my own fieldwork on these languages, except where noted otherwise.

\subsection{Phonological phrasing algorithms}

In all three languages, both syntax and focus play a role in determining the phonological phrasing. However, as we shall see, different syntactic constituents define neutral phonological phrasing in the three languages. Focus also plays a different role in each language. In all three languages, lengthening of the phrase penult syllable is the easiest to identify - and most consistent - correlate of prosodic phrasing. (Parentheses in the data indicate prosodic phrasing.) Although this cannot be effectively transcribed, it should be noted that in all three languages, the penult of the sentence-final prosodic phrase is noticeably longer than the penults of sentence-medial prosodic phrases. That is, sentence penult vowles have culminative lengthening at the sentence level. (We return to this point in section 3.1, below.)

\subsubsection{Durban Zulu prosodic phrasing}

Cheng \& Downing $(2007 \mathrm{a}, \mathrm{b})$ show that prosodic phrasing in Durban Zulu is almost identical to that of Xhosa, a closely related Nguni Bantu language analyzed by Jokweni (1995). Under broad focus, there is a prosodic phrase break at the right edge of CP (roughly, a clause), as shown below: ${ }^{1}$

1 In the morpheme-by-morpheme glosses in all of the data, the numbers indicate the agreement class (or gender) of the noun and the verbs and modifiers which are required to 
(3) Durban Zulu neutral phrasing

(a) The teacher read to the parents a letter.

$\begin{array}{clcl}\text { [cP (úm-fúndísi } & \text { ú-fúndel-ê: } & \text { ábá-zal' } & \text { ín-cwa:di)]. } \\ \text { 1-teacher } & \text { 1-read to-TAM } & \text { 2-parent } & \text { 9-letter }\end{array}$

(b) We believe that the children are playing outside.

\begin{tabular}{|c|c|c|}
\hline $\begin{array}{l}\text { (Si-khólwa } \\
\text { we-believe }\end{array}$ & $\begin{array}{l}\text { [Cp úkúth' } \\
\text { that }\end{array}$ & $\begin{array}{l}\text { ábá-ntwána } \\
\text { 2-child }\end{array}$ \\
\hline
\end{tabular}

(c) The man who is wearing a hat saw the visitors.

$\begin{array}{cllll}\text { [CP [DP [CP (Ín-dod' } & \text { é-gqoke } & \text { ísí-gqo:ko)] } & \text { í-bon-é } & \text { ízi-vaká:shi)]. } \\ \text { 9-man } & \text { REL9-wear } & \text { 7-hat } & \text { 9-see-TAM } & \text { 8-visitor }\end{array}$

(d) We like the hat the man is wearing.

\begin{tabular}{|c|c|}
\hline $\begin{array}{l}\text { [cp (si-thánd' } \\
\text { we-like }\end{array}$ & [DP [CP ísí-gqok' \\
\hline
\end{tabular}

Focus only indirectly conditions prosodic phrasing in Durban Zulu. Focused verb complements must occur in Immediately After the Verb (IAV) position, and a prosodic phrase break separates them from any other postverbal complements. This is illustrated by the Wh-question and answer pairs in (4a, b), below. The answer to a Wh-question on the subject is clefted, and clefts are obligatorily set off by a prosodic phrase break, as shown in (4ci). Cheng \& Downing $(2007 \mathrm{a}, \mathrm{b})$ argue that these phrasings are also consistent with proposing a prosodic phrase break at the right edge of $\mathrm{CP}$, as the right edge of a cleft and the right edge of IAV position correspond to the right edge of CP.

(4) Durban Zulu focused postverbal complements and clefts Right dislocations - WH particle and answer-both focused-are in IAV

(a) Q-What did the visitors buy for their families?
(ízí-vaká:shi)
zí-yí-thengel-ê:-ni)
(ímí-ndeni
yâ:zo)?
10 -visitors
10SM-OM4-buy for-TAM-what
4-families
4.their

A-The visitors bought clothing for their families.
(ízí-vakáshí
bá-yí-thèngel-é
ízí-ngu:bo)
(ímí-ndeni yâ:bo).
10 -visitors
2SM-OM4-buy for-TAM 10-clothes
4-families 2.their

agree with the noun. For example, in (3a), the word for 'teacher' is in agreement class 1. As it is the subject, the verb's subject prefix is also from agreement class 1. (See Doke 1954 and Mchombo 2004 for more discussion of Bantu agreement class systems.) Other frequently used abbreviations in the morpheme-by-morpheme glosses are: REL 'relativizer'; Cop 'copula'; TAM 'tense/aspect marker'; OM 'object agreement prefix'; Loc 'locative'. 
(b) Q What did the teacher give to the winner?
(úm-fúndís'
ú-m-nik-ê:-ni)
(ó-wín-i:le)?
1-teacher
1-OM1-give-TAM-Q
Rel1-win-TAM

A The teacher gave a medal to the winner.

$\begin{array}{llll}\text { (úm-fúndí:sí) } & \text { ú-m-nikez-é: } & \text { í-méndlè:la) } & \text { (ó-wín-i:le). } \\ \text { 1-teacher } & \text { 1-OM1-give-TAM } & \text { 5-medal } & \text { Rel1-win-TAM }\end{array}$

Clefts - note distinction in tone on the first syllable of the head of cleft vs. non cleft

(ci) clefted subject, Answers, 'Who is playing at school?'

The children are playing at school. = It is the children who are playing at school.
(Abá-ntwa:n')
(abá-dlal'
é-sí-kóle:-ni).
CoP2-child
REL2-play
Loc-7- school-Loc

(cii) subject relative

The children who are playing at the school live near the school.
(Ábá-ntwán'
ábá-dlal'
é-sí-kóle:-ni)
(bá-hlál'
édúzáne
2-child
REL2-play Loc-7-school-Loc
2-live
near
nésí-kó:le).
to.7-school

To sum up this section, in Zulu, prosodic phrasing is syntactically conditioned by the right edge of CP. Focus plays an indirect role in conditioning prosodic phrasing. Clefts and the IAV focus position arguably are each at the right edge of a $\mathrm{CP}$, and so also condition a prosodic phrase break by the usual phrasing algorithm.

\subsubsection{Chichewa prosodic phrasing}

As Kanerva's (1990) detailed study of prosodic phrasing in Chichewa shows, under neutral phrasing a smaller syntactic constituent (roughly, XP) conditions prosodic phrase breaks in this language. The subject NP, VP (verb and all its complements) and a Topic NP are the three potential syntactic subconstituents of the clause in Kanerva's analysis. ${ }^{2}$ Each of these is parsed into its own prosodic phrase. Note that prosodic phrases, like the syntactic phrases they parse, can contain a single prosodic word:

(5) Chichewa neutral phrasing (Kanerva 1990)

$\begin{array}{lllll}\text { (a) (fiisi) } & \text { (a-na-gúlá } & \text { chi-péwá } & \text { ku-San Francíscó } & \text { dzuulo) } \\ \text { 1.hyena } & \text { 1-TAM-buy } & \text { 7-hat } & \text { Loc-San Francisco } & \text { yesterday }\end{array}$

The hyena bought a hat in San Francisco yesterday.

2 See Bresnan \& Mchombo (1987), Bresnan \& Kanerva (1989) and Mchombo (2004) for detailed discussion of this syntactic approach to Chichewa sentence structure. 
$\begin{array}{llll}\text { (b) (aána) } & \text { (a-na-góná } & \text { m-nyumbá } & \text { yá mávúuto) } \\ \text { 2.child } & \text { 2-TAM-sleep } & \text { Loc-9.house } & 9.0 \text { Mavuto }\end{array}$

The children slept at Mavuto's house.

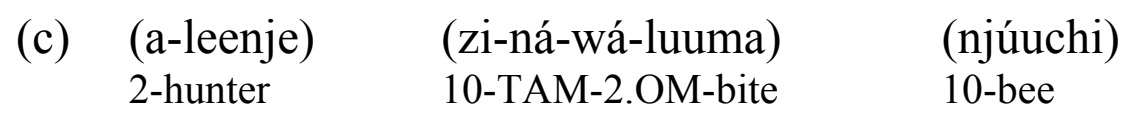

The hunters, they bit them, the bees [did].

Unlike Durban Zulu, Chichewa allows in situ focus of verb complements. As Kanerva's (1990) work shows, we find the following pattern of phrasing under focus. A prosodic phrase boundary follows a constituent in narrow focus, and non-focused VP complements are each parsed into a separate prosodic phrase. Downing et al's (2004) work on a different variety of Chichewa shows that VPfinal focused constituents are preceded by a prosodic phrase boundary in some varieties of Chichewa. This study also confirms Myers' (1996) observation that the phrase containing the focused element is raised in pitch, indicated with an upward arrow, in some varieties. (Focus raising is discussed briefly in section 4.2, below.) The data in (6) and (7) are from Downing et al.'s (2004) study of Ntcheu Chichewa:

(6) S/he hit the house with a rock.

$\begin{array}{lll}\text { (a) /A-ná-meny-a } & \text { nyumbá ndí mwalá/ } \\ \text { s/he-SIMPLE PAST-hit-FV } & \text { house } & \text { with rock }\end{array}$

(b) broad VP focus

(A-ná-mény-a nyumbá ndí mwáálá).

(c) Oblique PP focus

Q (A-ná-ménya nyuúmbá) (ndí mwáálá) (kapéná ndí ndoodo)?

'Did s/he hit the house with a rock or with a stick?

A (A-ná-mény-a nyuúmbá) (ndí mwáálá) $\uparrow$.

(d) Object NP focus

Q (A-ná-ménya chiyáani) (ndi mwáálá)?

'What did s/he hit with the rock?'

(e) $\mathrm{V}$ focus

Q (Nyuúmba) (i-ná-táá-ní)?

'What happened to the house?'

A (A-ná-méeny-a) $\uparrow$ (nyuúmbá) (ndí mwáálá). 
(7) The chief gave the child clothes.

(a) broad VP focus
(M-fúumu)
(i-ná-páts-a
mw-aná
zóóváala).
9-chief
9-SIMPLE PAST-give-FV 1-child
10.clothes

(b) Direct Object NP focus

Q (A-ná-páts-a mw-aáná) (chiyáani)?

What did he give to the child?

A (A-ná-páts-a mw-aáná) (zóóváala) $\uparrow$.

(c) Indirect Object NP focus

Q (A-ná-pátsa ndáání) (zóóváala)?

'Who did he give clothes to?'

A (A-ná-páts-a mw-aáná) $\uparrow \|$ (zóóváala).

To sum up this section, in Chichewa, prosodic phrase breaks are syntactically conditioned by the major subconstituents of the clause: Subject, VP and Topic.

Focus plays a direct role in conditioning prosodic phrasing, as constituents within the VP must be set off by a prosodic phrase break when they are focused in situ.

\subsubsection{Chitumbuka prosodic phrasing}

Downing (2006) shows that neutral prosodic phrasing in Chitumbuka is conditioned by the right edge of NP. ${ }^{3}$ As in Chichewa, this means that Subject NPs and Topics are phrased separately from the rest of the clause. In contrast to Chichewa, the entire VP does not form a single prosodic phrase unless the VP is very short. Instead, a verb plus its first complement form a single phrase, and following complements are generally phrased separately. As a result, the neutral phrasing of VPs in Chitumbuka is essentially identical to the focus-induced phrasings of VPs in Chichewa which were illustrated in (6) and (7). Compare in particular (8e), below, with (6c, d):

(8) Chitumbuka neutral phrasing

(a) We are cooking porridge.

(ti-ku-phika sî:ma) we-TAM-cook 9.porridge

(b) The children help the friends.
([ß]-â:na)

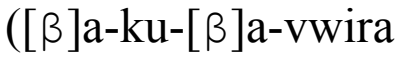
2-child
2-TAM-2.OM-help
[ß]a-bwê:zi)
2-friend

3 Chitumbuka is the least well studied of these three languages. There is no thesis length work on prosodic phrasing or even a grammar of the language. See Downing (2006) for a preliminary sketch of the syntax and prosody of focus in Chitumbuka. 
(c) We saw a thief at the market.

(ti-ka-wona mu-nkhúngu ku-msî:ka).

we-TAM-see 1-thief Loc-3.market

(d) The women sewed clothes for the bride.

$\begin{array}{lllll}\text { ([ß]-anakâ:zi) } & \text { ([ß]a-ka-sona } & \text { vy-akuvwara } & \text { vya } & \text { mu-kwâ:ti.) } \\ \text { 2-woman } & \text { 2-TAM-sew } & \text { 8-clothes } & \text { 8.of } & \text { 1-bride }\end{array}$

(e) The boy hit a house with a rock.

$\begin{array}{lllll}\text { (m-nyamâ:ta) } & \text { (wa-ka-timba } & \text { nyû:mba) } & \text { (na } & \text { lî:bwe). } \\ \text { 1-boy } & \text { 1-TAM-hit } & \text { 9.house } & \text { with } & \text { 5.rock }\end{array}$

Focus regularly conditions prosodic rephrasing in two main contexts in Chitumbuka. The answer to a Wh-question and a Wh-question particle are followed by a prosodic phrase break, as shown in (9a) vs (9b) and in (10).

(9) Wh-Qs on verb complements and Answers

(a) The woman washes clothes for the children. [neutral reading]

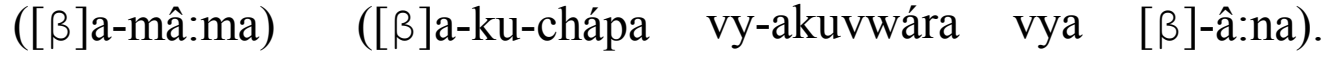
2P-woman 2P-TAM-wash 8-clothes 8.of 2-child

(b)

Q- Who does the woman wash clothes for?
(Kâ:si)
([ß]a-mâ:ma
[ß]a-ku-chapíra
njâ:ni) (vy-akuvwâ:ra)?
$\mathrm{Q}$ 2P-woman 2P-TAM-wash for
1.who 8-clothes

A- The woman washes clothes for the children.

$\begin{array}{llll}\text { ([ß]a-mâ:ma) } & \text { ([ß]a-ku-chapíra } & {[\beta] \text {-â:na) }} & \text { (vy-akuvwâ:ra). } \\ \text { 2P-woman } & \text { 2P-TAM-wash for } & \text { 2-child } & \text { 8-clothes }\end{array}$

(10)

Q- Who did you buy the green mangoes for at the shop?
(U-ka-mu-gulira njâ:ni) (mango ya $[\beta] \hat{i}: s i)$ (ku-gorosâ:ri)? 1-TAM-1.OM-buy for 1.who 6.mango 6.of unripe
LOC-grocery

A- I bought green mangoes for my friend at the shop.

(N-kha-mu-gulira mu-nyâ:ne) (mango ya [ß]1̂:si) (ku-gorosâ:ri).

I-TAM-1.OM-buy for 1-my friend 6.mango 6.of unripe Loc-grocery

Association with focus morphemes - pera 'only'; -so 'also'; yaye 'no; not' are also followed by an obligatory prosodic phrase break, as shown in (11):

(11) Association with focus (Downing 2006)

(a) pera 'only'

They showed their homes only to the visitors.

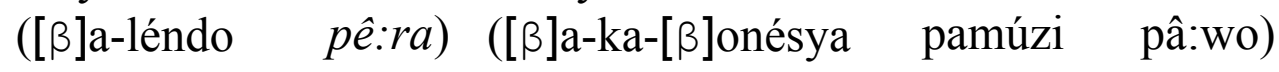
2-visitor only 2-TAM-show homes their 
(b) -so 'also'

Are you also weeding the maize?

(Ku-limilirâ:-so) $\quad$ (ngô:mâ:)?
You/TAM-weed-also

(c) yaye 'no; not'

The monkey did not make the child cry.

$\begin{array}{clcc}\text { (m-bwê:ngu) } & \text { (wa-ka- lísya } & \text { yâ:ye) } & \text { (mw-â:na). } \\ \text { 1-monkey } & \text { 1-TAM-make cry } & \text { not } & \text { 1-child }\end{array}$

To sum up, in Chitumbuka, prosodic phrase breaks are syntactically conditioned by noun phrase edges, though an entire VP can be parsed into a single prosodic phrase if it is short. Focus plays a direct role in conditioning prosodic phrasing. Constituents within the VP which are focused in situ (i.e., WH-questions and answers) must be followed by a prosodic phrase break. Association with focus particles must also be followed by a prosodic phrase break.

\subsection{Phrasal stress and focus}

As we have seen, in all three of these Bantu languages, the prosodic phrase is the domain for the lengthening of phrase-penult syllables. (See Downing (to appear) for a recent survey of penult stress in Bantu languages.) Indeed, duration is a common cross-linguistic correlate of stress, as noted in work like Hyman (1977) and Odden (1999). We have also seen that, in all three languages, prosodic phrasing is conditioned by focus, at least indirectly. As a result, focused constituents often have a prosodic phrase boundary at their right edge, and so receive phrasal stress. We noted, though this cannot be effectively transcribed, that the penult of the sentence-final prosodic phrase is noticeably longer than sentence-medial lengthened penults in all three languages. This gives the sentence-final penult culminative prominence in the sentence. With this background in mind, we are prepared to consider whether these languages support the PROMINENCE-Focus correlation in (1). This question is taken up in the next section.

\section{Mismatches between stress and focus}

In this section I argue that the following mismatches between stress and focus in Chichewa, Durban Zulu and Chitumbuka show that there is no correlation between the position of prosodic prominence and focus. First, sentence stress realized as extra penult lengthening-remains fixed on the final word of an utterance; it is not attracted to focus. Phrasal stress is also fixed on the last word of the phrase, not necessarily the one in narrow focus. Finally, we shall see that 
in Chitumbuka, the productive focus particle, $-s o$ - the equivalent of English also introduced briefly in (11), above - attracts phrasal stress to its verbal host, not to its focused argument.

\subsection{Sentence stress remains fixed in utterance final position}

The Prominence-Focus correlation in (1) requires focused constituents, as heads of the Intonation Phrase (roughly equivalent to a clause), to have the culminative prosodic prominence within their domain - that is, they should have the highest level of some measurable prosodic property associated with prominence, such as duration, pitch or intensity. This correlation is satisfied if stress is flexible, as in English and other Germanic languages, and moves to the stressed position, as shown in (2), above. It is also satisfied if word order is flexible, as in Italian and Hungarian (Samek-Lodovici 2005, Szendroï 2003), and focused words move to the stressed position. It can also be satisfied, as in Danish (Grønnum 1998) or French (Beyssade et al. 2004, Féry 2001), if pitch is compressed in non-focal constituents, lending focused constituents passive prominence. In all three of these Bantu languages, though, the highest degree of stress (defined as vowel lengthening) in the sentence is fixed on the penult syllable of the final prosodic phrase in the sentence. Downing et al.'s (2007) exploratory phonetic study shows that penults in the sentence-final prosodic phrase are significantly lengthened in Chichewa compared to sentence-medial (non-prepausal) phrase penult vowels. The penult vowels of phrases containing focused elements are never longer than penults in sentence-final phrases. My informal phonetic analysis of Durban Zulu and Chitumbuka shows a similar pattern for these languages.

In short, the final constituent in a sentence is always made the most prosodically prominent in these three languages through penult lengthening, whether it contains the focused constituent or not. ${ }^{4}$ This clearly violates the PROMINENCE-FoCUS correlation.

\subsection{Phrasal stress remains fixed in phrase final position}

In the data presented so far, entire XPs were in focus, and often these XPs (especially the noun phrases and prepositional phrases) and the prosodic phrases which parse them consist of just one prosodic word. In all of these cases, phrasal stress occurs in a position that is consistent with scope of focus as defined in Selkirk (1995), either the phrase-final word or the entire XP. A look at data illustrating contrastive focus in more complex XPs in the three languages shows

4 See Zerbian (2006) for detailed discussion of a similar finding for Northern Sotho. 
that prosodic phrase boundaries fall at the right edge of the XP containing the focused word, and phrase stress falls consistently on the phrase penult syllable. This leads to mismatches between the position of phrasal stress and the position of focus, if the focused word is not at the right edge of its XP.

These points are illustrated by the Chitumbuka data in (12). As we can see, contrastive focus is clearly on the word towards the left edge of the prosodic phrase, but phrasal stress is assigned to the non-focused word which occurs at the right edge of the prosodic and syntactic phrase, leading to a mismatch between phrasal stress and focus:

(12) Chitumbuka (Downing field notes)

(a)

Q- Did the child carry the basket for an old man or an old woman?

$\begin{array}{lllll}\text { (Mw-â:ná) } & \text { (wa-ka-yeyera } & \text { chi-tê:te) } & \text { (dada mu-chekû:rû:) } \\ \text { 1-child } & \text { 1-TAM-carry for } & \text { 7-basket } & \text { 1.man } & \text { 1-old } \\ \text { (panyákhe } & \text { mw-anakazi } & \text { mu-chekû:ru)? } & \\ \text { or } & \text { 1-woman } & \text { 1-old } & \end{array}$

A- The child carried the basket for an old man.

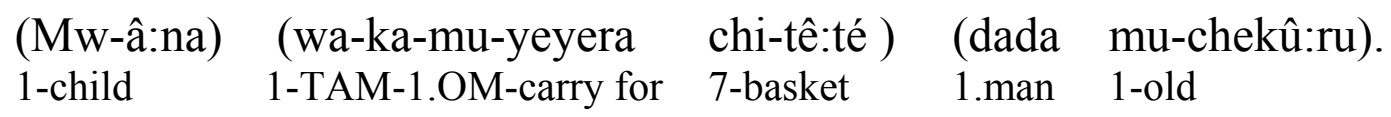

(b)

Q- Is he building the new houses in the village or outside the village?

\begin{tabular}{|c|c|c|c|c|c|}
\hline $\begin{array}{l}\text { (Kâ:si, } \\
\text { Q }\end{array}$ & $\begin{array}{l}\text { wa-ku-zenga } \\
1 \text {-TAM-build }\end{array}$ & $\begin{array}{l}\text { nyumba } \\
10 \text { house }\end{array}$ & $\begin{array}{l}\text { zî:-pyá) } \\
\text { 10-new }\end{array}$ & $\begin{array}{l}\text { (mu-kati } \\
\text { Loc-in }\end{array}$ & $\begin{array}{l}\text { mwa-mû:zî:) } \\
\text { Loc-village }\end{array}$ \\
\hline -nváá á-ná & he ku-walo & kwa-n & û:zi)? & & \\
\hline
\end{tabular}

A- He is building some new houses in the village (and) some outside.

$\begin{array}{lllll}\text { (Wa-ku-zenga } & \text { nyumba } & \text { zi-nyákhe } & \text { mu-kati } & \text { mwa-mû:zí) } \\ \text { 1-TAM-build } & \text { 10.house } & 10 \text {-some } & \text { Loc-in } & \text { Loc-village } \\ \text { (zi-nyákhe } & \text { kuwâ:lo). } & & & \\ \text { 10-some } & \text { Loc-outside } & & & \end{array}$

Similar phrasing and prominence assignment for similar data are found in Chichewa and Durban Zulu (Downing field notes), as shown by the data in $(13):^{5}$

5 In $(13 \mathrm{c}, \mathrm{d})$ we see that a left-dislocated NP can be parsed into a separate prosodic phrase from what follows in Zulu. This is surprising, given the generalization from section 2.1.1 that prosodic phrases align with the right edge of a clause. See Cheng \& Downing (2007b) for an analysis of this phrasing pattern. 
(13)

Chichewa

(a) Q Did the child carry the basket for the old man or the old woman?

$\begin{array}{lllll}\text { (Mw-aáná) (a-ná-nyámulira dengu } & \text { bambo } & \text { wókálaamba) } \\ \text { 1-child } & \text { 1-TAM-carry for } & \text { 5.basket } & 1 . \text { man } & \text { 1.old } \\ \text { (kapená } & \text { máí } & \text { wókálaamba)? } & & \\ \text { or } & \text { 1.woman } \quad \text { 1.old }\end{array}$

(b) A She carried the basket for the old man, not the old woman.

\begin{tabular}{|c|c|c|c|}
\hline (A-ná-nyámulira & dengu & bambo & wókálaamba) \\
\hline 1-TAM-carry for & 5.basket & 1.man & 1.old \\
\hline $\begin{array}{cl}\text { (ósatí } & \text { máí } \\
\text { not } & 1 . \text { woman }\end{array}$ & $\begin{array}{l}\text { wókála } \\
\text { 1.old }\end{array}$ & & \\
\hline
\end{tabular}

Zulu

(c) Q Did the chief build houses inside our village or outside?

$\begin{array}{lllll}\text { (ín-du:na) } & \text { (izí:-ndlu) } & \text { (í-z-akh-é: } & \text { é-sí-gódi-ni } & \text { se:thu) } \\ \text { 9-chief } & \text { 10-house } & \text { 9-10.om.build-TAM } & \text { Loc-7-village-Loc } & \text { 7.our } \\ \text { (nomá } & \text { nga-phá:ndle)? } & & \\ \text { or } & \text { Loc-outside } & & \end{array}$

(d) A The chief built houses inside our village, not outside.

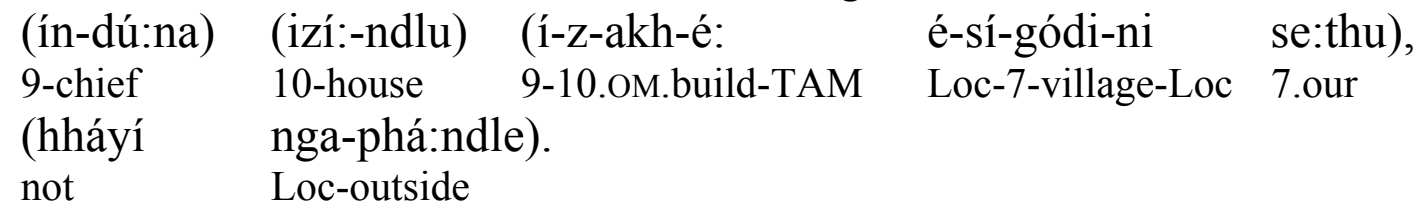

This pattern of focus-prominence mismatch within NPs and/or Prepositional Phrases has parallels in Swahili (Geitlinger \& Waldburger 1999), as well as in non-Bantu languages like Italian (Ladd 1996, Swerts et al. 2002) and Egyptian Arabic (Hellmuth 2005). In all these languages, the generalization is the same: prosodic phrasing respects XP constituent edges, and phrasal prominence remains fixed on the phrase-final word. Prominence does not highlight a prefinal focused element within the phrase.

\subsection{No sentence level stress on arguments of focus particles}

In English, sentence-level stress marks all types of focus, including focus on the italicized argument of association with focus particles like 'also' in (14c): 
(14)

(a) Where are you going to eat dinner on Friday?

We are going to an Italian restaurant for dinner on Friday.

(b) We are going to an Italian restaurant, not a Thai restaurant.

(c) We are also going to an Italian restaurant on Saturday night.

However, the analogous focus particle in Chitumbuka - the association-withfocus verbal enclitic, -so 'also; again'- does not lend culminative prosodic prominence to its focused argument. As shown in (15) - (18), below, it attaches only to verbs and is itself followed by a prosodic phrase boundary (indicated with parentheses). As a result, both the verb host and the word the enclitic puts in focus realize the same prominence-related prosody - penult lengthening and contour tone - which correlates with prosodic phrase boundaries. This leads to potential ambiguity about what is in focus. For example, in (17b), the subject, the verb, the verb phrase or the object could be interpreted as the argument of -so without the context in (17a) to disambiguate:

(a) (n-khu-limilíra ma-pû:no).

I-TAM-weed 6- tomatoes

'I am weeding tomatoes.'

(b) (Ku-limilirâ:-so) (ngô:mâ:)?

You/TAM-weed-also 9. maize

'Are you also weeding the maize?'

(16) The friend who killed the snake also brought their father to the hospital.

(Mu-nya[ß]o uyo wa-ka-yi-koma n-jô:ka) (ndiyo wa-k-izâ:-so)

1-friend 1.REL 1-TAM-9.OM-kill 9-snake is.who 1-TAM-bring-also

(na $[\beta] a-d a d a \quad[\beta]-a ̂:[\beta] o) \quad$ (ku-chi-patâ:la).

with 2P-father 2P-their Loc-7-hospital

(17)

(a) Q- Is it only the doctor who helps the teacher?

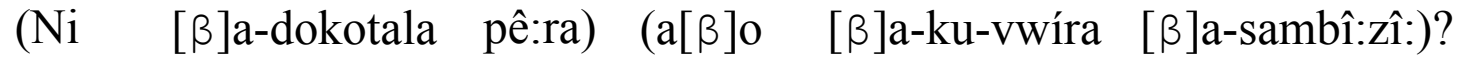

COP 2P-doctor only 2P.REL 2P-TAM-help 2P-teacher

(b) A- No, the chief also helps the teacher.

$\begin{array}{llll}\text { (Yâ:yí), } & ([\beta] \mathrm{a}-f u ́ m u & [\beta] \mathrm{a}-k u-v w i r a ̂:-s o) & ([\beta] \mathrm{a}-\mathrm{sambî}: z i) . \\ \text { no } & \text { 2P-chief } & \text { 2P-TAM-help-also } & \text { 2P-teacher }\end{array}$ 
(18)

(a) Q- Are you going to Lilongwe today?

$\begin{array}{llll}\text { (Kâ:si), } & \text { (mu-ku-luta } & \text { ku-Lilô:ngwe) } & \text { (mw-ahû:nô:)? } \\ \text { Q } & \text { you-TAM-go } & \text { Loc-Lilongwe } & \text { today }\end{array}$

(b) A- Yes, and I am also going to Salima.

(Ê:nya), (n-khu-lutâ:-so) (ku-Salî:ma).

yes I-TAM-go-also Loc-Salima

Work by Rooth (1992) on focus-related morphemes has argued that focus particles like -so should be morphologically and phonologically uninteresting. The focused argument of these morphemes should be made prominent either phonologically, by having the same focus prosody as other focus constructions, like Q/A pairs and in situ contrastive focus, or morphologically, by adjacency of the focusing morpheme and its argument. However, in Chitumbuka, the focused argument of the focus particle is not always made prominent by either phonology or morphology. Data like (17b) shows that -so is not always morphosyntactically adjacent to its argument. And while the focus particle triggers prosodic rephrasing, its focused argument is not unambiguously highlighted by any culminative sentence-level prosody.

\section{$4 \quad$ Intonation and information structure}

Intonation in the sense of pitch manipulation does not play a consistent and striking role in signaling focus or other aspects of information structure in these languages. However, it does play some role, and this will be briefly sketched in this section.

\subsection{Question intonation}

In Zulu, there is no special prosody associated with Wh-questions. In both Chichewa and Chitumbuka, the overall pitch of yes-no questions is higher than statements, and there is an Intonational rise-fall (or fall-fall) melody over the final two syllables of the question, as shown by the data below: ${ }^{6}$

6 See Myers $(1996,1999)$ for a detailed phonetic study of question intonation in Chichewa, and see Downing et al. $(2004,2007)$ for more detailed discussion of focus raising in one variety of Chichewa. 
(19) Chitumbuka (Downing field notes)

(a) Did the goats jump over the wall?

$\begin{array}{cccc}\text { Kási, } & \text { mbû:zi } & \text { zi-ka-duka } & \text { pa-chi-phû:phâ:? } \\ \text { Q } & \text { 10.goats } & \text { 10-TAM-jump } & \text { Loc-7- wall }\end{array}$

(b) Did the monkey make the child cry?

$\begin{array}{llll}\text { Kási, } & \text { mbwê:ngu } & {[\beta] \text { a-ka-lilisya }} & \text { mw-â:nâ:? } \\ \text { Q, } & \text { 1.monkey } & \text { 1-TAM-make cry } & \text { 1-child }\end{array}$

(20) Chichewa (Downing field notes)

(a) Did the dog make the child laugh?

$\begin{array}{llll}\text { Kódí, } & \text { gaálu } & \text { a-ná-seketsa } & \text { mw-àánâ:? } \\ \text { Q } & \text { 1.dog } & \text { 1-TAM-make laugh } & \text { 1-child? }\end{array}$

(b) Are the boys feeding the pigs?

$\begin{array}{llll}\text { Kódí, } & \text { a-nyamáàta } & \text { a-ku-dyétsa } & \text { nkhùúmbâ:? } \\ \text { Q } & \text { 2-boys } & \text { 2-TAM-feed } & \text { 10.pigs }\end{array}$

These intonation patterns are found elsewhere in Bantu languages. Ashton (1947) shows that Swahili yes-no questions are marked by a rise-fall melody over the last two syllables. An overall raised pitch for yes/no questions is found in Northern Sotho (Zerbian 2004, 2006) and Jita (Downing 1996). Indeed, as Yip (2002) shows, it is fairly common for tone languages to use boundary tones or an overall raising of pitch register to mark questions. Lexical tone does not preclude the intonational use of pitch. It is rather surprising, then, that these languages do not indicate focus by use of sentential pitch prominence, as intonational melody (and register) are manipulated to distinguish statements from questions.

\subsection{Focus register raising in Chichewa}

Although Chichewa does not use sentential stress or accent to indicate focus, Downing et al. $(2004,2007)$ have shown that in some varieties of Chichewa, phrasal register raising accompanies focus. (Myers (1996: fn 8) also mentions the occurrence of focus register raising in Chichewa, but unfortunately provides no phonetic details.) Downing et al.'s main finding - briefly summarized in table 1 - is that focus leads to systematic raising of $\mathrm{f}_{0}$ within the Phonological Phrase containing the focused element. The table 1 provides the mean maximal pitch values for the Phonological Words in (6b, c, d, e), above, repeated below the table for convenience: 
Table 1: Bolding highlights the significantly raised $\mathrm{f}_{0}$-values (in $\mathrm{Hz}$; and their $\mathrm{sd}$ in parentheses) of the Prosodic Words under focus (underlined) as revealed by Scheffé post hoc tests for an ANOVA over pitch maxima split by Phonological Word $(* *: p<.01 ; *$ : $p<.05)$. Bold cell borders indicate Phonological Phrasing. The duration in $\mathrm{ms}$ of pauses is given in column 'p:'; the ' $N$ ' column indicates the number of repetitions out of 5 containing a pause at that position.

\begin{tabular}{|c|c|c|c|c|c|}
\hline & a-ná-mé(e)ny-a & nyu(ú)mbá & $\mathrm{p}:[\mathrm{ms}]$ & $\mathrm{N}$ & ndí-mwáálá \\
\hline (6b) & $147.6(3.96)$ & $113.7(2.96)$ & - & - & $110.9(3.18)$ \\
\hline (6c) & 144.0 & 115.2( & 193.2 & 2 & $120.0(6.02) *$ \\
\hline (6d) & 154.1( & $134.4(15.22)^{* * *}$ & $252.7(52.43)$ & 5 & $109.6(3.63)$ \\
\hline$(6 e)$ & $179.0(11.9) * *$ & $109.9(4.21)$ & 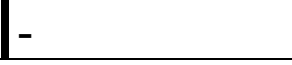 & - & $101.2(1.37)$ \\
\hline
\end{tabular}

(6) S/he hit the house with a rock.

(a) /A-ná-meny-a nyumbá ndí mwalá/ S/he-SIMPLE PAST-hit-FV house with rock

(b) (A-ná-mény-a nyumbá ndí mwáálá).

(c) (A-ná-mény-a nyuúmbá) (ndí mwáálá) $\uparrow$.

(d) (A-ná-mény-a nyuúmbá) $\uparrow \|$ (ndí mwáálá).

(e) (A-ná-méeny-a) $\uparrow$ (nyuúmbá) (ndí mwáálá).

The mean maximal pitch values in table 1 show that the pitch of High tone sequences in the Phonological Phrase containing the narrowly focused element (underlined) is significantly higher (bolded) than when the same constituent is not focused. Note that downstep is not reset by focus raising. High tones undergo declination across the sentence in all the data. We also find a pattern of declination between High-toned sequences within the Phonological Phrase (set off by bolded vertical lines). As a result, the focused element does not have the highest pitch in its phrase (or in the sentence), unless it is also sentence or phrase initial. In short, focus raising does not lead to culminative pitch prominence for focused elements at either the phrase or the sentence level.

\section{Conclusion}

To conclude, let us return to the questions that we started off with. First, do Chichewa, Durban Zulu and Chitumbuka have sentence-level prominence? As we have seen, yes, they do all have culminative sentential prominence, realized as significant lengthening of the sentence-penult syllable. One contribution of the paper, then, is to point out that pitch is not the only form of prosody that can serve intonation's role of marking sentence and phrase edges. Secondly, does sentence prominence correlate with focus? $\mathrm{No}$, as we have seen, in these languages sentence prominence is fixed at the end of the sentence, but focus can 
occur in an earlier prosodic phrase. Focus register raising, found in some varieties of Chichewa, also does not give culminative pitch prominence to the focused element. Finally, does phrasal prominence correlate with focus? No, as we have seen, phrasal prominence is fixed on the phrase-penult syllable. The focused word need not be in a position in the phrase where it can receive phrasal prominence. Further, focus particles in Chitumbuka highlight their host, not necessarily their arguments.

In short, these are languages where re-phrasing provides a prosodic correlate of focus but sentence-level prominence does not. This study adds to the body of work showing that re-phrasing is an important cross-linguistic correlate of focus (Hyman 1999, Ladd 1996, Jun 1996, Hayes \& Lahiri 1991). Sentence level prominence is conditioned only by syntax, and plays the important demarcative function of identifying sentence edges. Another contribution of the paper is, then, to emphasize that the demarcative and focus functions of sentence- and phrase-level prosody are separable. The same prosody is not recruited to fill both functions in all languages the way it is, for example, in English.

\section{References}

Ashton, E.O. 1947. Swahili Grammar (including Intonation). 2d edition. London: Longmans.

Beyssade, C., E. Delais-Roussarie, J. Doetjes, J.-M. Marandin \& A. Rialland. 2004. Prosody and information in French. In F. Corblin \& H. de Swart (eds.). Handbook of French Semantics. Stanford: CSLI, 477-499.

Bresnan, J. \& J. Kanerva. 1989. Locative inversion in Chichewa: a case study of factorization in grammar. Linguistic Inquiry 20, 1-50.

Bresnan, J. \& S. Mchombo. 1987. Topic ,pronoun and agreement in Chichewa. Language 63, 741-782.

Bruce, G. 1977. Swedish Word Accents in Sentence Perspective. Travaux de l'Institut de Linguistique de Lund XII.

Cheng, L. \& L. Downing. 2007a. The prosody and syntax of Zulu relative clauses. Bantu in Bloomsbury: Special Issue on Bantu Linguistics. SOAS WPL 15, 51-63.

Cheng, L. \& L. Downing. 2007b. Where's the topic in Zulu? ms. University of Leiden \& ZAS. [under review]

Cruttenden, Alan. 1997. Intonation. $2^{\text {nd }}$ edition. Cambridge: Cambridge University Press.

Doke, C. M. 1954. The Southern Bantu Languages. London: Oxford University Press.

Downing, L. J. 1996. The Tonal Phonology of Jita. Munich: LINCOM Europa.

Downing, L.J. 2006. The prosody and syntax of focus in Chitumbuka. In L.J. Downing, L. Marten \& S. Zerbian (eds.), Papers in Bantu Grammar and Description. ZASPiL 43, 55-79. 
Downing, L. J. to appear. Accent in African languages. In R.W.N. Goedemans, H.G. van der Hulst \& E.A. van Zanten (eds.), Word Prosodic Systems in the Languages of the World. Berlin: Mouton.

Downing, L. J., A. Mtenje \& B. Pompino-Marschall. 2004. Prosody and information structure in Chichewa. ZASPiL 37, 167-186.

Downing, L. J., A. Mtenje \& B. Pompino-Marschall. 2007. The focus prosody of Chichewa and the Stress-Focus constraint: a response to Samek-Lodovici (2005). Under review.

Féry, C. 2001. Focus and phrasing in French. In C. Féry \& W. Sternefeld (eds.), Audiatur Vox Sapientiae: A Festschrift for A. v. Stechow. Berlin: Akademie Verlag, 153-181.

Geitlinger, K. \& D. Waldburger. 1999. Intonation in Swahili. Brücken und Grenzen: Werkschau Afrikastudien 2. Münster: LIT Verlag, 419-434.

Grønnum, N. 1998. Intonation in Danish. In Daniel Hirst \& Albert Di Cristo (eds.), Intonation Systems: A Survey of Twenty Languages. Cambridge University Press, 131-151.

Gussenhoven, C. 1984. On the Grammar and Semantics of Sentence Accents. Dordrecht: Foris.

Gussenhoven, C. 1996. Sentence accents and argument structure. In I.M. Roca (ed.), Thematic Structure: Its Role in Grammar. Berlin: Foris, 79-106.

Gussenhoven, C. 2004. The Phonology of Tone and Intonation. Cambridge University Press.

Hayes, B. \& A. Lahiri. 1991. Bengali Intonational Phonology. NLLT 9: 47-96.

Hellmuth, S. 2005. No de-accenting in (or of) phrases: Evidence from Arabic for crosslinguistic and cross-dialectal prosodic variation. In S. Frota, M. Vigário \& M. J. Freitas (eds.), Prosodies. Berlin: Mouton de Gruyter, 99-121.

Hyman, L. M. 1977. On the nature of linguistic stress. In Larry Hyman (ed.), Studies in Stress and Accent. SCOPIL 4. Los Angeles: University of Southern California, 37-82.

Hyman, L. M. 1999. The interaction between focus and tone in Bantu. In G. Rebuschi \& L. Tuller (eds.), The Grammar of Focus. Amsterdam: John Benjamins, 151-177.

Jokweni, M. W. 1995. Aspects of IsiXhosa Phrasal Phonology. Ph.D. dissertation, University of Illinois at Urbana-Champaign.

Jun, S.-A. 1996. The Phonetics and Phonology of Korean Prosody. New York: Garland.

Jun, S.-A. 2005. Prosodic Typology. In Sun-Ah Jun (ed.), Prosodic Typology: The Phonology of Intonation and Phrasing. Oxford: Oxford University Press, 430-458.

Kanerva, J. 1990. Focus and Phrasing in Chichewa Phonology. New York: Garland.

Ladd, D. R. 1996. Intonational Phonology. Cambridge: Cambridge University Press.

Mchombo, S. 2004. The Syntax of Chichewa. Cambridge: Cambridge University Press.

Myers, S. 1996. Boundary tones and the phonetic implementation of tone in Chichewa. SAL 25, 29-60.

Myers, S. 1999. Downdrift and pitch range in Chichewa intonation. Proceedings of ICPhS99, 1981-1984. 
Odden, D. 1999. Typological issues in tone and stress in Bantu. In S. Kaji (ed.), Crosslinguistic Studies of Tonal Phenomena: Tonogenesis, Typology, and Related Topics. Tokyo: ILCAA, 187-215.

Reinhart, T. 1995. Interface strategies. OTS Working Papers in Theoretical Linguistics 02001, Utrecht: OTS, Utrecht University.

Roberts, C. 1998. Focus, the flow of information, and universal grammar. In The Limits of Syntax, Syntax and Semantics 29, 109-160. Academic Press.

Rooth, M. 1992. A theory of focus interpretation. Natural Language Semantics: 75-116.

Rooth, M. 1996. Focus. In S. Lappin (ed.), Handbook of Contemporary Semantic Theory. Oxford: Blackwell, 271-297.

Samek-Lodovici, V. 2005. Prosody-syntax interaction in the expression of focus. NLLT 23: 687-755.

Selkirk, E. O. 1984. Phonology and Syntax: The Relation between Sound and Structure. Cambridge, Mass.: MIT Press.

Selkirk, E. O. 1995. Sentence prosody: intonation, stress and phrasing. In J. A. Goldsmith, (ed.), Handbook of Phonological Theory. Cambridge, Mass.: Blackwell, 550-569.

Selkirk, E. O. 2004. Bengali intonation revisited. In C. Lee, M. Gordon \& D. Büring (eds.), Topic and Focus: A Cross-Linguistic Perspective. Dordrecht: Kluwer, 217-246.

Swerts, M., E. Krahmer \& C. Avesani. 2002. Prosodic marking of information status in Dutch and Italian: a comparative analysis. Journal of Phonetics 30, 629-654.

Szendröi, K. 2003. A stress-based approach to the syntax of Hungarian focus. The Linguistic Review 20: 37-78.

Truckenbrodt, H. 1995. Phonological Phrases: Their Relation to Syntax, Focus, and Prominence. Ph.D. dissertation, MIT.

Yip, M. 2002. Tone. Cambridge: Cambridge University Press.

Zerbian, S. 2004. Intonation in Northern Sotho. Poster presented at the TIE Conference, Santorini, 9-11 September 2004.

Zerbian, S. 2006. Expression of Information Structure in the Bantu Language Northern Sotho. Ph.D. dissertation, Humboldt-University Berlin. [published as ZASPiL 45]. 